\title{
Spore surface glycoproteins of Colletotrichum lindemuthianum are recognized by a monoclonal antibody which inhibits adhesion to polystyrene
}

\author{
H. Bleddyn Hughes, ${ }^{1}$ Raffaella Carzaniga, ${ }^{2}$ Sarah L. Rawlings, ${ }^{1}$ \\ Jonathan R. Green ${ }^{1}$ and Richard J. O'Connell ${ }^{2}$
}
1 School of Biological Sciences, University of Birmingham, Birmingham B15 2T, UK
2 IACR-Long Ashton Research Station, Department of Agricultural Sciences, University of Bristol, Long Ashton, Bristol BS41 9AF, UK

\author{
Author for correspondence: Richard J. O'Connell. Tel: +44 1275 392181. Fax: +44 1275394281. \\ e-mail : richard.oconnell $(a)$ bbsrc.ac.uk
}

\begin{abstract}
Conidia (spores) of Colletotrichum lindemuthianum, a fungal plant pathogen causing bean anthracnose, adhere to the aerial parts of host plants to initiate the infection process. These spores possess a fibrillar 'spore coat' as well as a cell wall. In a previous study a mAb, UB20, was raised that recognized glycoproteins on the spore surface. In this study UB20 was used to localize and characterize these glycoproteins and to investigate their possible role in adhesion. Glycoproteins recognized by UB20 were concentrated on the outer surface of the spore coat and, to a lesser extent, at the plasma membrane/cell wall interface. Extraction of spores with hot water or $0.2 \%$ SDS resulted in removal of the spore coat. Western blotting with UB20 showed that a relatively small number of glycoproteins were extracted by these procedures, including a major component at $110 \mathrm{kDa}$. Biotinylation of carbohydrate moieties, together with cell fractionation, confirmed that these glycoproteins were exposed at the surface of the spores. In adhesion assays, $>90 \%$ of ungerminated conidia attached to polystyrene Petri dishes within $30 \mathrm{~min}$. UB20 IgG at low concentrations inhibited attachment in an antigen-specific manner. This suggests that the glycoproteins recognized by this mAb may function in the initial rapid attachment of conidia to hydrophobic substrata. Polystyrene microspheres bound selectively to the $110 \mathrm{kDa}$ glycoprotein in Western blots, providing further evidence that this component could mediate interactions with hydrophobic substrata.
\end{abstract}

Keywords: Colletotrichum lindemuthianum, adhesion, conidia, extracellular matrix, cell wall

\section{INTRODUCTION}

Colletotrichum is a large genus of plant-pathogenic fungi which cause devastating diseases (anthracnoses) on a wide range of temperate and tropical crops (Bailey et al., 1992). The spores (conidia) of Colletotrichum species are dispersed by rain splash and to initiate disease they must rapidly adhere to the aerial parts of host plants (Mercure et al., 1994a). Following germination, the spore produces a short germ tube, which

Abbreviations: endo- $\mathrm{H}$, endo- $\beta-N$-glucosaminidase- $\mathrm{H}$; $\mathrm{PA} / \mathrm{TCH} / \mathrm{SP}$, periodic acid/thiocarbohydrazide/silver proteinate; PNGase, peptide- $N$ glycosidase; TCS, tissue culture supernatant. in turn develops an appressorium required for initial penetration of the plant cuticle and cell wall (Bailey et al., 1992). The conidia are produced in acervuli embedded in a water-soluble mucilage composed of high molecular mass glycoproteins (Nicholson, 1992). This mucilage contains germination inhibitors and a variety of enzymes and may function to protect conidia from desiccation and toxic plant metabolites (Nicholson, 1992). However, in the case of Colletotrichum graminicola, the acervular mucilage appears to play no role in spore adhesion (Mercure et al., 1994b). Evidence from Colletotrichum lindemuthianum, Colletotrichum musae and C. graminicola indicates that spore adhesion involves both passive hydrophobic interactions and processes requiring active spore metabolism (Sela- 
Buurlage et al., 1991; Young \& Kauss, 1984; Mercure et al., 1994b). Treatment with a proteolytic enzyme abolished conidial adhesion in C. musae and C. graminicola, suggesting that pre-formed proteins on the surface of spores are required for their initial hydrophobic attachment. In some Colletotrichum species, the subsequent release of protein exudates onto the substratum may consolidate initial attachment (Jones et al., 1995; Mercure et al., 1995). However, the conidia of other species, including C. lindemuthianum, do not appear to release any protein exudates (O'Connell et al., 1996).

In recent studies, we have shown that the spores of $C$. lindemuthianum, the bean anthracnose pathogen, possess a fibrillar 'spore coat' that is not found on germtubes or appressoria (O'Connell et al., 1996). The spore coat was identified using transmission electron microscopy of spores prepared by cryo-fixation and freezesubstitution, but was not preserved by conventional chemical fixation and dehydration. In transverse section, the spore coat is approximately $60 \mathrm{~nm}$ thick and appears to be composed of densely packed fibres arranged perpendicular to the cell wall (O'Connell et al., 1996). Oblique sections reveal that the spore coat contains irregularly shaped pores, giving it a reticular or honeycomb-like appearance. Fibrillar surface layers with similar ultrastructure have been observed on conidia of Colletotrichum truncatum, C. graminicola, Discula umbrinella and on various yeasts prepared by freeze-substitution (Walther et al., 1988; Van Dyke \& Mims, 1991; Viret et al., 1994; Mims et al., 1995). The fibrillar cell coat of Candida albicans also has a porous structure (Bobichon et al., 1994) and mannoproteins in this layer are responsible for the hydrophobicity of the cell surface and control the adhesion of this pathogen to host cells (Hazen \& Hazen, 1992).

Lectin and $\mathrm{mAb}$ probes have been used to analyse the cell surfaces of $C$. lindemuthianum spores and other infection structures (O'Connell et al., 1996). These studies showed that the carbohydrate composition of the spore surface differs in several respects from that of germ tubes and appressoria. For example, the plant lectin Bauhinia purpurea agglutinin, which recognizes terminal $\mathrm{N}$-acetyl-D-galactosamine and D-galactose residues (Goldstein \& Poretz, 1986), labelled the surface of spores intensely, but labelled germ tubes and appressoria only weakly (O'Connell et al., 1996). mAb UB20, which recognizes a carbohydrate epitope on glycoproteins, also preferentially labelled conidia (Pain et al., 1992). In this study, a combination of cytochemical and biochemical techniques was used to analyse the cell surface (spore coat and cell wall) of ungerminated $C$. lindemuthianum spores. The spore coat was removed from intact spores by extraction with hot water or $0 \cdot 2 \%$ SDS and within these extracts we identified a major $110 \mathrm{kDa}$ glycoprotein that was labelled by mAb UB20. Attachment of ungerminated spores to polystyrene was inhibited by UB20 IgG, suggesting that the glycoproteins recognized by this $m A b$ could mediate the initial rapid attachment of conidia to hydrophobic substrata.

\section{METHODS}

Fungal culture and preparation of washed spores. Cultures of C. lindemuthianum (Sacc. \& Magn.) Briosi \& Cav. race $\kappa$ (Long Ashton Research Station Culture Collection number 137) were maintained as described previously (Pain et al., 1992). Conidia were prepared by washing the surface of 6 -dayold sporulating cultures with $15 \mathrm{ml}$ distilled water per culture flask and filtering through a $45 \mu \mathrm{m}$ nylon mesh before centrifugation at $1200 \mathrm{~g}$ for $10 \mathrm{~min}$. Acervular mucilage was removed by washing the spores three times by resuspension in $15 \mathrm{ml}$ volumes of distilled water and centrifugation as above. This process typically yielded $1 \times 10^{8}$ washed spores from each flask.

mabs. mAbs were used in the form of tissue culture supernatants (TCS) produced by growing mouse hybridoma cell lines. For adhesion experiments, $\operatorname{IgG}$ was purified from the mAb TCS using a Protein G column (Johnston \& Thorpe, 1987). mAb UB20, raised to germinating conidia of $C$. lindemuthianum, recognizes a carbohydrate epitope present on cell surface glycoproteins (Pain et al., 1992). mAb UBIM22, raised to rat bone cells (Perry et al., 1990), was used as a negative control.

Preparation of frozen sections. Washed spores were fixed in a mixture of $1 \%(\mathrm{v} / \mathrm{v})$ glutaraldehyde and $4 \%(\mathrm{w} / \mathrm{v})$ paraformaldehyde in $50 \mathrm{mM}$ sodium phosphate buffer, $\mathrm{pH} \mathrm{7.2}$, for $16 \mathrm{~h}$ at $4{ }^{\circ} \mathrm{C}$. After rinsing in $50 \mathrm{mM}$ glycine in buffer, pelleted spores were mixed with an equal volume of $4 \%(w / v)$ lowgelling-temperature agarose (Sigma Type IX) in buffer and aliquots $(40 \mu \mathrm{l})$ were placed in $200 \mu \mathrm{l}$ microcentrifuge tubes and centrifuged for $3 \mathrm{~min}$ at $11000 \mathrm{~g}$. After cooling on ice, the tube tip containing the pellet was removed and infiltrated sequentially with $0 \cdot 25,0 \cdot 5,1$ and $1.5 \mathrm{M}$ sucrose in buffer $(1 \mathrm{~h}$ each) at $4{ }^{\circ} \mathrm{C}$. The sucrose-infiltrated pellets were mounted on aluminium pins and rapidly frozen in subcooled nitrogen. Sections were cut with tungsten-coated glass knives using a Reichert Ultracut microtome equipped with an FC4 cryosectioning attachment. Ultrathin sections (approx. $0.1 \mu \mathrm{m}$ thick) were obtained at $-100{ }^{\circ} \mathrm{C}$ and mounted on Formvarcoated 100 mesh gold EM grids.

Immunocytochemistry. For immunogold labelling of ultrathin frozen sections, grids were floated on drops of reagent in the following sequence: (a) $5 \%(\mathrm{v} / \mathrm{v})$ normal goat serum, $6 \%$ $(\mathrm{w} / \mathrm{v})$ BSA, $0 \cdot 1 \%(\mathrm{v} / \mathrm{v})$ fish skin gelatin and $50 \mathrm{mM}$ glycine in PBS, $30 \mathrm{~min}$; (b) undiluted TCS of mAbs UB20 or UBIM22 or polyclonal rabbit anti- $\beta$-1,3-glucan antibodies (Genosys) diluted $1: 2000$ in PBS containing $1 \%$ BSA (PBSA), 18 h at $4{ }^{\circ} \mathrm{C} ;(\mathrm{c})$ five changes of PBSA, 3 min each; (d) repetition of step (a); (e) goat anti-mouse $\operatorname{IgG}$ antibodies or goat anti-rabbit $\operatorname{IgG}$ antibodies conjugated with 10 or $15 \mathrm{~nm}$ colloidal gold (British Biocell International), respectively, diluted $1: 50$ in PBSA, $1 \mathrm{~h}$; (f) five changes of PBSA, 3 min each; (g) five changes of deionized water, 3 min each. Sections were then stained for $5 \mathrm{~min}$ in $2 \%(\mathrm{v} / \mathrm{v})$ uranyl oxalate on ice, embedded in $2 \%$ $(\mathrm{w} / \mathrm{v})$ methyl cellulose containing $0 \cdot 2 \%(\mathrm{w} / \mathrm{v})$ uranyl acetate for $10 \mathrm{~min}$ on ice and air-dried (Tokuyasu, 1986) before observation by transmission electron microscopy (TEM).

Freeze substitution and localization of carbohydrates. Unwashed, unimbibed spores were collected by touching pieces $(3 \times 3 \mathrm{~mm})$ of autoclaved dialysis membrane onto the surface of sporulating cultures. Washed spores were resuspended in $20 \mu \mathrm{l} 1 \%(\mathrm{w} / \mathrm{v})$ molten low-gelling-temperature agarose and mounted on Formvar-coated platinum loops (Lancelle et al., 1986). In other experiments, washed spores were extracted with hot water or $0.2 \%(\mathrm{w} / \mathrm{v})$ SDS (see below) or treated with 
$5 \mathrm{mg}$ Pronase $\mathrm{E} \mathrm{ml^{-1 }}$ (Sigma) in $10 \mathrm{mM} \mathrm{Tris} / \mathrm{HCl}$ buffer ( $\mathrm{pH} \mathrm{7.6)} \mathrm{for} 60 \mathrm{~min}$ at $36^{\circ} \mathrm{C}$ prior to embedding in agarose. All samples were frozen by plunging into liquid propane cooled to between -185 and $-190{ }^{\circ} \mathrm{C}$ (Howard $\&$ O'Donnell, 1987), freeze-substituted in acetone containing $1 \%(\mathrm{w} / \mathrm{v})$ osmium tetroxide and $0 \cdot 2 \%(\mathrm{w} / \mathrm{v})$ uranyl acetate and embedded in Epon/Araldite resin. Ultrathin sections were mounted on Formvar-coated gold slot grids and stained with uranyl acetate and lead citrate or with periodic acid/ thiocarbohydrazide/silver proteinate (PA/TCH/SP) to detect carbohydrates (Roland \& Vian, 1991). Control sections were treated with $6 \%(\mathrm{v} / \mathrm{v})$ hydrogen peroxide in place of periodic acid.

Preparation of spore surface extracts. Washed spores (approx. $1 \times 10^{8}$ ) were resuspended either in $250 \mu$ l deionized distilled water $\left(\mathrm{ddH}_{2} \mathrm{O}\right)$ containing $0.2 \%(\mathrm{w} / \mathrm{v})$ SDS and $1 \mathrm{mM}$ PMSF or in $250 \mu \mathrm{lddH_{2 }}$ O containing $1 \mathrm{mM}$ PMSF only. The spore suspension was heated at $90^{\circ} \mathrm{C}$ for $10 \mathrm{~min}$ to extract surface material. Control spores were incubated at $20^{\circ} \mathrm{C}$ in $\mathrm{ddH}_{2} \mathrm{O}$ containing $1 \mathrm{mM}$ PMSF. The spores were then pelleted at $11600 \mathrm{~g}$ for $1 \mathrm{~min}$ and the supernatant collected. Samples for SDS-PAGE were diluted with $5 \times$ reducing sample buffer (see below). To extract proteins remaining after treatment, the final spore pellet was washed

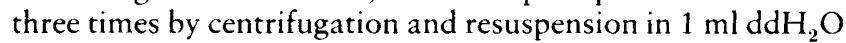
before heating at $90^{\circ} \mathrm{C}$ for $10 \mathrm{~min}$ in $100 \mu \mathrm{l}$ reducing sample buffer and homogenizing with a Dounce homogenizer, followed by addition of a further $150 \mu$ l reducing sample buffer. The homogenized spores were pelleted as described above and the supernatant collected.

Isolation of spore cell walls. Washed spores (approx. $9 \times 10^{8}$ ) were resuspended in $30 \mathrm{ml} 0.2 \mathrm{M}$ sucrose in $20 \mathrm{mM}$ MOPS buffer $(\mathrm{pH} 7 \cdot 2$ ) containing $50 \mu \mathrm{l}$ of a fungal protease inhibitor cocktail (Sigma cat. no. P8215) and frozen overnight at $-80^{\circ} \mathrm{C}$. The spores were then disrupted by three passes through an X-Press homogenizer (AB Biox) pre-cooled to $-80^{\circ} \mathrm{C}$. A cell-wall-enriched fraction was prepared by centrifugation at $1400 \mathrm{~g}$ for $10 \mathrm{~min}$ at $4^{\circ} \mathrm{C}$. To remove adherent membranes, this pellet was resuspended in $15 \mathrm{ml}$ $0 \cdot 1 \%(\mathrm{v} / \mathrm{v})$ Triton X-100 in MOPS/sucrose buffer containing protease inhibitors and incubated for $10 \mathrm{~min}$ at $4{ }^{\circ} \mathrm{C}$. After centrifugation, the pellet was resuspended in $2 \times$ sample buffer (see below).

SDS-PAGE and Western blotting. Samples in reducing sample buffer $[0.0625 \mathrm{M}$ Tris $/ \mathrm{HCl}, 10 \%$ (v/v) glycerol, $2 \%(\mathrm{w} / \mathrm{v})$ SDS, $5 \%(\mathrm{v} / \mathrm{v}) \beta$-mercaptoethanol and $0.0013 \%(\mathrm{w} / \mathrm{v})$ bromophenol blue; $\mathrm{pH} \mathrm{6.8}$ ] were denatured at $70^{\circ} \mathrm{C}$ for $15 \mathrm{~min}$, briefly microcentrifuged and loaded $(20 \mu \mathrm{l}$ per lane) onto a $7.5 \%(\mathrm{w} / \mathrm{v})$ polyacrylamide minigel (Mini-Protean II, BioRad). Following separation by SDS-PAGE, proteins were either stained with Coomassie blue R-250 or Western-blotted. Samples for Western blotting were transferred to nitrocellulose (Hybond-C, Amersham International), blocked overnight in $10 \mathrm{mg} \mathrm{BSA} \mathrm{ml}^{-1}$ in PBS at $4{ }^{\circ} \mathrm{C}$ and then incubated in $1 \mathrm{ml}$ TCS diluted with $2 \mathrm{ml}$ PBS containing $5 \mathrm{mg} \mathrm{BSA} \mathrm{ml}^{-1}$ (PBSA) for $1 \mathrm{~h}$ at room temperature. The blots were washed three times in PBS and then incubated in rabbit anti-mouse IgG antibodies conjugated with alkaline phosphatase (Dako), diluted 1:1000 in PBSA, for $1 \mathrm{~h}$ at room temperature. Blots were then washed two times for $5 \mathrm{~min}$ each in PBS and once in $0.05 \%(\mathrm{v} / \mathrm{v})$ Tween 20 in PBS before developing in substrate (Pain et al., 1992).

To detect hydrophobic proteins, blots of spore surface extracts prepared with hot water were blocked in BSA as above and then incubated directly with polystyrene microspheres diluted $1: 10$ in PBS for $1 \mathrm{~h}$ and washed $(3 \times 10 \mathrm{~min})$ in PBS. Redstained polystyrene latex microspheres $(0.465 \mu \mathrm{m}$ diam.) were supplied as a stock solution of $2.65 \%(\mathrm{w} / \mathrm{v})$ solids (Polybeads; Polysciences cat. no. 15708). Similar microspheres have been shown to be hydrophobic and have been used to assay surface hydrophobicity in various fungi (Hazen \& Hazen, 1987; Clement et al., 1994).

Biotinylation of spore surface glycoproteins. The carbohydrate moieties of spore surface glycoproteins were biotinylated with biotin hydrazide using a method modified from Kähne \& Ansorge (1994). Washed spores were resuspended in $0.5 \mathrm{mM}$ sodium metaperiodate in PBS and incubated at room temperature for $15 \mathrm{~min}$ in the dark to mildly oxidize the hydroxyl groups of carbohydrates. After washing five times by centrifugation and resuspension in PBS, the spores were resuspended in $5 \mathrm{mM}$ biotin hydrazide (Sigma) in PBS and incubated for $30 \mathrm{~min}$ at room temperature. The treated spores were then washed three times by centrifugation and resuspension in $\mathrm{ddH}_{2} \mathrm{O}$ before extraction of surface proteins in $0.2 \%(\mathrm{w} / \mathrm{v}) \mathrm{SDS}$, as described above. The extracted proteins, and proteins remaining in the spore pellet, were separated by SDS-PAGE and Western-blotted. For detection of biotinylated glycoproteins, blots were blocked and incubated in rabbit anti-biotin antibodies conjugated with alkaline phosphatase (Sigma) diluted 1:5000 in PBSA, before development as described above.

Antigen modification experiments. Spore surface extracts prepared with $0.2 \%$ SDS were treated with peptide- $N$ glycosidase (PNGase) and endo- $\beta$ - $N$-glucosaminidase- $H$ (endo-H) to determine the nature of carbohydrate side-chains present on glycoproteins recognized by mAb UB20. Samples $(80 \mu \mathrm{l})$ of the extract were diluted with $20 \mu \mathrm{l} 5 \times$ concentration buffers to produce samples in PNGase buffer $[20 \mathrm{mM}$ sodium phosphate buffer, $50 \mathrm{mM}$ EDTA, $0.5 \%(\mathrm{w} / \mathrm{v})$ SDS, $5 \%(\mathrm{v} / \mathrm{v})$ $\beta$-mercaptoethanol, $0.02 \%(\mathrm{w} / \mathrm{v})$ sodium azide, $1 \mathrm{mM}$ PMSF, $\mathrm{pH} 7 \cdot 5]$ or endo-H buffer [ $100 \mathrm{mM}$ sodium citrate-phosphate buffer, $0 \cdot 16 \%$ (w/v) SDS, pH 5.5]. Samples of $1 \mathrm{mg}$ bovine RNase B ml ${ }^{-1}$ (Sigma) were prepared in the above buffers as positive controls for enzyme digestion. All samples were denatured by heating at $95^{\circ} \mathrm{C}$ for $2 \mathrm{~min}$ prior to enzyme treatment. For PNGase digestion, $35 \mu \mathrm{l}$ protein sample was incubated with $5 \mu \mathrm{l} 10 \%(\mathrm{w} / \mathrm{v})$ octylglucoside and $10 \mu \mathrm{l}(2$ units) PNGase (Oxford Glycosystems). For endo-H digestion,

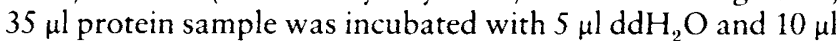
(10 milliunits) endo-H (Oxford Glycosystems). In control experiments, $\mathrm{ddH}_{2} \mathrm{O}$ was substituted for the enzymes. The samples were incubated for $18 \mathrm{~h}$ at $37^{\circ} \mathrm{C}$ before dilution with $2 \times$ reducing sample buffer and separation by SDS-PAGE and Western blotting with mAb UB20. RNase B controls were run on $15 \%(\mathrm{w} / \mathrm{v})$ polyacrylamide gels under reducing conditions and stained with Coomassie blue R-250. For $\beta$-elimination, ELISA plates were coated with spore proteins extracted with hot water which had been incubated overnight in $0.1 \mathrm{M}$ $\mathrm{NaOH}$ at $37^{\circ} \mathrm{C}$ followed by neutralization with $\mathrm{HCl}$. Plates were then incubated with UB20, followed by rabbit antimouse IgG antibodies conjugated with alkaline phosphatase and the appropriate substrate (Pain et al., 1992).

Spore adhesion assay. The effect of mAbs on the attachment of spores to polystyrene was assessed using a method adapted from Mercure et al. (1994b). Washed spores from 7-day-old cultures were diluted to a concentration of $1 \times 10^{6}$ spores $\mathrm{ml}^{-1}$ using distilled water. Aliquots of the spore suspension $(75 \mu \mathrm{l})$ were incubated for $15 \mathrm{~min}$ with an equal volume of purified UB20 or UBIM22 IgG diluted in distilled water to give final 
concentrations ranging from 0 to $100 \mu \mathrm{g} \operatorname{lgG~ml}{ }^{-1}$. After marking squares $(5 \times 5 \mathrm{~mm})$ on the base of polystyrene Petri dishes $(5 \mathrm{~cm}$ diameter, Sterilin), droplets $(50 \mu \mathrm{l})$ of treated spore suspension were placed within these marked areas and incubated for $30 \mathrm{~min}$ at $20^{\circ} \mathrm{C}$. An inverted microscope with a $\times 25$ objective was then used to count the number of spores in 10 random fields of view within each marked area (three areas per dish, one dish per treatment). After adding $6 \mathrm{ml}$ distilled water, the dishes were agitated for $10 \mathrm{~s}$ at 500 r.p.m. on an orbital shaker and the number of remaining spores was counted in 10 random fields of view within the same marked areas. Percentage adhesion was calculated by dividing the number of conidia that remained attached by the number which had originally settled onto the polystyrene.

To assess the relative hydrophobicity of the polystyrene Petri dishes and host tissue, water contact angles were measured using a microscope goniometer (Ramé-Hart) using the method of Neumann \& Good, 1979). Hypocotyl tissue was taken from 10-d-old seedlings of Phaseolus vulgaris cv. Kievitsboon Koekoek, grown as described by Pain et al. (1992). Measurements were taken from 30 replicate droplets $(1 \mu \mathrm{l})$ of $\mathrm{ddH}_{2} \mathrm{O}$ placed on each surface at $20^{\circ} \mathrm{C}$. Data are expressed as means \pm SEM.

\section{RESULTS}

\section{Ultrastructure of the spore surface after extraction by different procedures}

In resin sections through unwashed, unimbibed spores prepared by freeze-substitution, the spore coat was visible as a fibrillar outer layer distinct from the underlying cell wall and surrounding acervular mucilage (Fig. 1a). After staining with uranyl acetate and lead citrate, the spore coat appeared moderately electronopaque, while the cell wall was electron-lucent (Fig. 1a). However, both the spore coat and cell wall were stained intensely with the PA/TCH/SP procedure (Fig. 1b), indicating the presence of $\beta$-linked carbohydrates containing vicinal hydroxyl groups (Roland \& Vian, 1991). Granules with the typical ultrastructural appearance of glycogen were the only cytoplasmic components stained by PA/TCH/SP (Fig. 1b). No fungal structures were stained in control sections treated with hydrogen peroxide in place of periodic acid (Fig. 1f). The effect of several treatments used to extract cell surface components from spores (see below) was examined after PA/TCH/SP staining. Treatment with Pronase E (Fig. 1c), hot water (Fig. 1d) or $0.2 \%$ SDS (Fig. 1e) all removed the spore coat while leaving the cell wall intensely reactive with $\mathrm{PA} / \mathrm{TCH} / \mathrm{SP}$.

\section{Localization of polysaccharides and glycoproteins within the cell wall and spore coat}

Preliminary experiments showed that the antigens recognized by UB20 could not be detected in sections of spores prepared by freeze-substitution followed by lowtemperature embedding in resins. EM-immunogold labelling was therefore performed on ultrathin frozen sections (Fig. 2a-c). The cytoplasm of cryo-sectioned conidia showed good ultrastructure but membranes appeared negatively stained and, in contrast to freeze- substituted/resin-embedded conidia, it was not possible to clearly distinguish between the cell wall and spore coat. Nevertheless, several layers of differing electron opacity were visible at the cell surface and their combined thickness $(180 \mathrm{~nm})$ was equivalent to that of the cell wall and spore coat together, as judged from measurements made on resin sections of freeze-substituted conidia (Fig. 1b). Moreover, it was possible to specifically immunolabel the cell wall in frozen sections using a polyclonal antibody recognizing $\beta$-1,3-glucans (Fig. 2c). The spore coat and cytoplasmic components were not labelled by this antibody. The mAb UB20 labelled two distinct layers at the spore surface (Fig. 2a), namely the outer layer of the spore coat and the inner layer of the cell wall and cytoplasm adjoining the plasma membrane. The region between these two layers was only sparsely labelled. UB20 also labelled some small vacuoles within the cytoplasm (Fig. 2a). Antibody UBIM22 did not label any fungal structures (Fig. 2b).

\section{Extraction and analysis of spore surface glycoproteins}

Staining of SDS-PAGE gels with Coomassie blue revealed that spore surface extracts prepared with either hot water or $0.2 \%$ SDS contained three major proteins of $110,>200$ and $>230 \mathrm{kDa}$. Data for the hot-water extract are shown in Fig. 3 (lane A). After labelling blotted proteins with mAb UB20, the same banding pattern was observed in extracts prepared by both methods, with major bands at $>200,155$ and $110 \mathrm{kDa}$, and some minor bands, including one at $45 \mathrm{kDa}$. Data for the hot-water extract are shown in Fig. 3 (lane B). Since UB20 recognizes a carbohydrate epitope (Pain et al., 1992), these bands represent glycoproteins. A different range of glycoproteins was labelled by UB20 in the spore pellet remaining after hot-water extraction, while the glycoproteins at 110,155 and > $200 \mathrm{kDa}$ were almost completely removed from the spores (Fig. 3, lane C). The control antibody, UBIM22, labelled no proteins in the hot-water extract (Fig. 3, lane F).

The glycoproteins at $>200,155,110$ and $45 \mathrm{kDa}$ could not be extracted from spores with cold water $\left(20^{\circ} \mathrm{C}\right)$ alone (Fig. 3, lane D). In addition, Western blotting of the cold-water washings produced during the initial spore preparation (after concentration by freeze-drying) showed only minor labelling of these glycoproteins (Fig. 3, lane $G$ ). We therefore concluded that they are components of the spore surface and are not present in the water-soluble acervular mucilage which surrounds the spores. A cell wall/spore coat fraction isolated from homogenized spores was treated with Triton X-100 to remove any residual membrane contamination before Western blot analysis with UB20. The antibody labelled glycoproteins at $>200,155,110$ and $45 \mathrm{kDa}$ (Fig. 3, lane E), providing further evidence that these components are located in the cell wall and/or spore coat. Several other glycoproteins were also labelled.

When Western blots of spore surface proteins extracted with hot water were probed with polystyrene micro- 


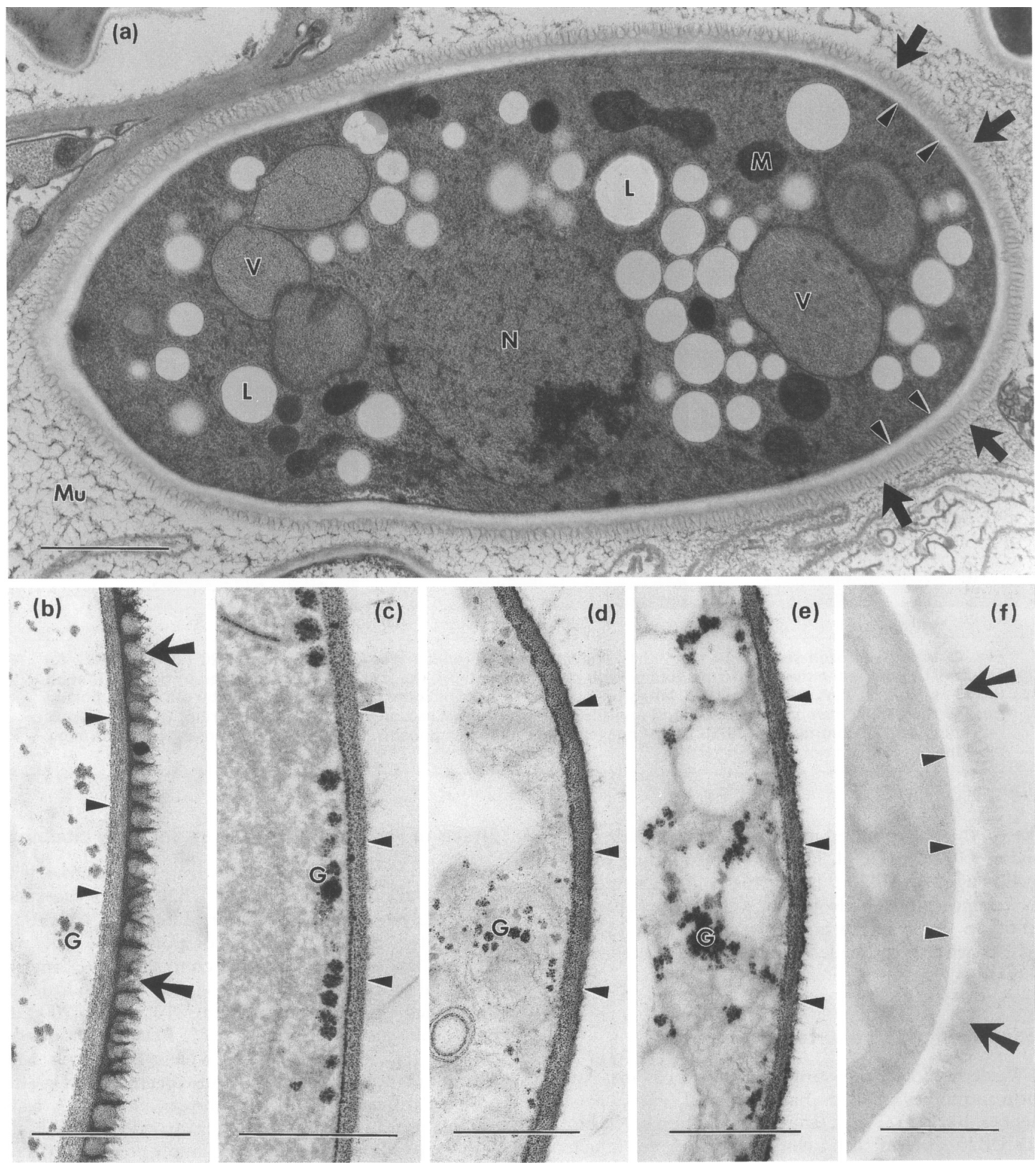

Fig. 1. Resin sections of $C$. lindemuthianum conidia prepared by freeze-substitution. (a) Unwashed, unimbibed conidium surrounded by acervular mucilage (Mu), stained with uranyl acetate and lead citrate. Note the electron-lucent cell wall (arrowheads) is covered by a fibrillar layer, the spore coat (arrows), which forms the outer surface of the cell. N, Nucleus; $L$, lipid globule; V, vacuole; M, mitochondrion. Bar, $1 \mu \mathrm{m}$. (b-f) Washed conidia stained with PATCH/SP. The spore coat (arrows), cell wall (arrowheads) and glycogen granules (G) are all stained intensely in control conidia (b). Note the spore coat is completely removed after treatment of cells with Pronase E (c), hot water (d) or $0.2 \%$ SDS in hot water (e). No fungal structures are stained in sections of control conidia treated with hydrogen peroxide in place of periodic acid ( $f$ ). Bars, $0.5 \mu \mathrm{m}$. 

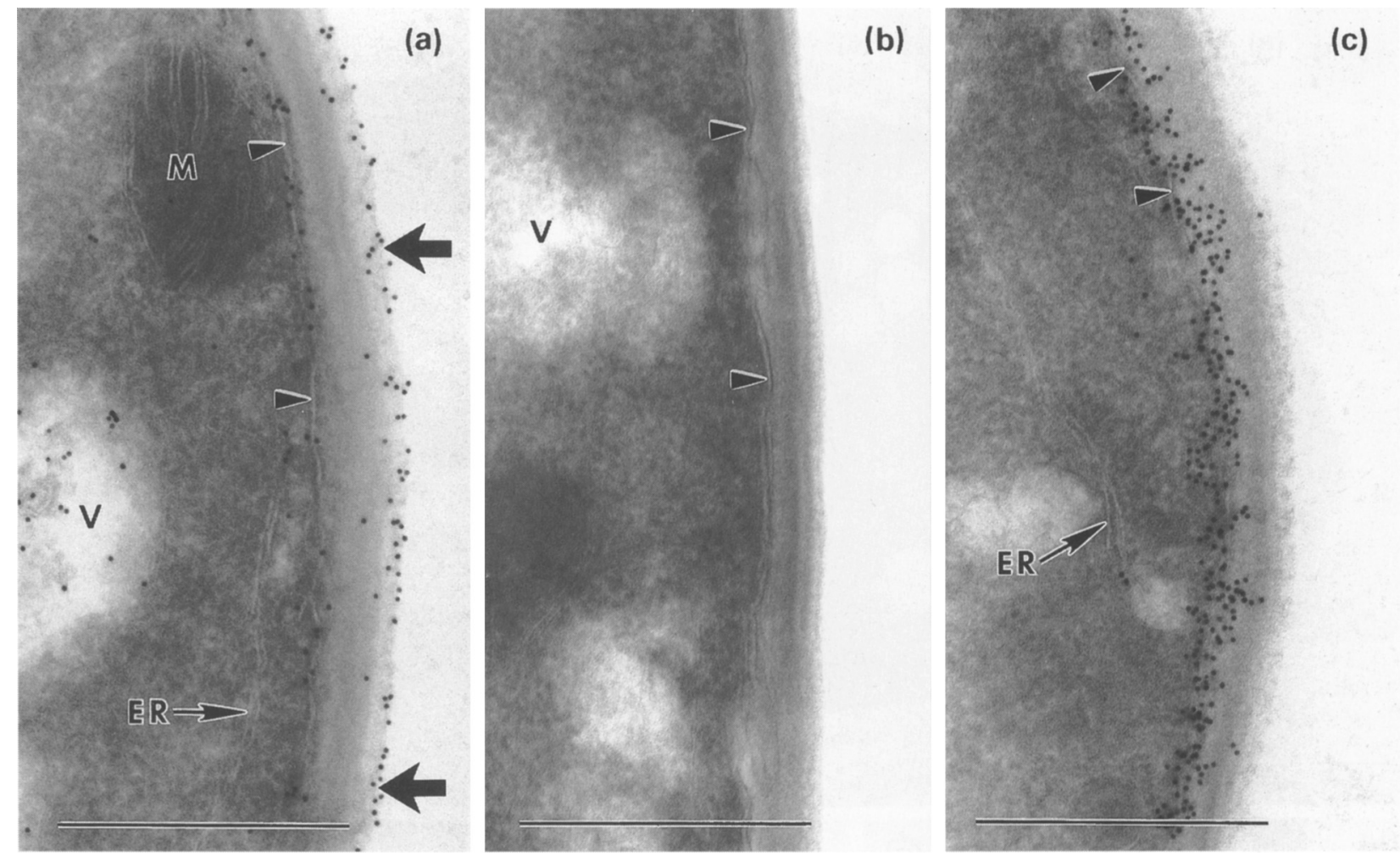

Fig. 2. Ultrathin frozen sections of washed $C$. lindemuthianum conidia labelled with mAb U820 (a) or UBIM22 (b) followed by goat anti-mouse $\mathrm{lgG} / 10 \mathrm{~nm}$ gold or with polyclonal anti- $\beta$-1,3-glucan antibodies followed by goat anti-rabbit lgG/15 nm gold (c). Bars, $0.5 \mu \mathrm{m}$. (a) UB20 labels the outer surface of the spore coat (large arrows), the cell wall/cytoplasm close to the plasma membrane (arrowheads) and the contents of small vacuoles ( $V$ ). M, Mitochondrion; ER, endoplasmic reticulum. (b) The control mAb UBIM22 does not label any spore components. (c) Anti- $\beta$-1,3-glucan antibodies strongly label the cell wall but not the spore coat.

spheres, the red-coloured particles selectively labelled a band at $110 \mathrm{kDa}$ (Fig. 4, lane B) corresponding to that labelled by mAb UB20 (Fig. 4, lane A), suggesting that this component is hydrophobic. Other glycoproteins present in the spore surface extracts $(>200,155$ and $45 \mathrm{kDa}$ ) were not labelled by the polystyrene microspheres.

\section{Biotinylation of spore surface glycoproteins}

In Western blots of biotinylated glycoproteins, antibiotin antibodies labelled a band at $110 \mathrm{kDa}$ and a broad smear $>200 \mathrm{kDa}$ (Fig. 5, lane B). Incubation of the blots with UB20 showed that identical bands were labelled with the antibody in both biotinylated (Fig. 5, lane A) and unbiotinylated samples (cf. Fig. 3, lane B). The results indicate that the 110 and $>200 \mathrm{kDa}$ glycoproteins identified by UB20 in spore surface extracts and isolated cell walls are accessible to biotin and are therefore exposed at the cell surface (Casanova et al., 1992). Both glycoproteins present in the extract were detected in reduced quantities in the spore pellet (Fig. 5, lane C). No proteins were labelled when an unbiotinylated spore extract was probed with antibiotin antibodies (Fig. 5, lane D).

\section{Effects of PNGase and endo-H on antibody binding}

Removal of $N$-linked carbohydrate side-chains with PNGase abolished binding of UB20 to all the spore surface glycoproteins in Western blots (Fig. 6, lane B), except for the $>200 \mathrm{kDa}$ component, which was labelled less intensely than the control (Fig. 6, lane A). Removal of high-mannose side-chains with endo- $\mathrm{H}$ did not affect UB20 binding to the 110 and $>200 \mathrm{kDa}$ bands, but the glycoprotein at $155 \mathrm{kDa}$ was no longer labelled (Fig. 6, lane C). The RNase-B controls were reduced in molecular mass by the expected $1.5 \mathrm{kDa}$ after both treatments (results not shown). In ELISA tests, removal of $O$-linked carbohydrate side-chains by $\beta$ elimination did not reduce UB20 binding to spore surface glycoproteins in hot-water extracts (results not shown).

\section{Inhibition of spore adhesion by mAb UB20}

The ability of mAbs to inhibit spore adhesion was assessed using an assay which measures the attachment of spores to polystyrene Petri dishes. Polystyrene was selected as an appropriate model substratum for this assay because its hydrophobicity (water contact angle = $91 \cdot 8 \pm 0 \cdot 9^{\circ}$ ) was very similar to that of host tissue, i.e. bean hypocotyls (water contact angle $=86 \cdot 3 \pm 1 \cdot 1^{\circ}$ ) 


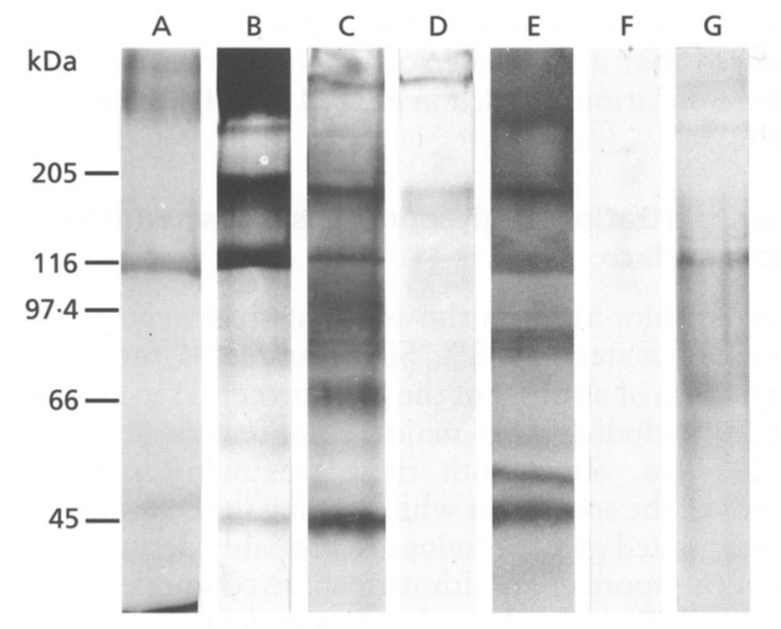

Fig. 3. Extraction of glycoproteins from C. lindemuthianum spores and analysis by SDS-PAGE and Western blotting. Lanes: $A$, hot-water $\left(90^{\circ} \mathrm{C}\right)$ extract stained with Coomassie blue; $B$, Western blot of hot-water extract probed with mAb UB20; $C$, Western blot of proteins remaining in the spore pellet after hot-water extraction, probed with UB20; D, Western blot of cold-water $\left(20^{\circ} \mathrm{C}\right)$ extract, probed with UB20; E, Western blot of isolated cell wall/spore coat fraction, probed with UB20; $F$, Western blot of hot-water extract, probed with control mAb UBIM22; G, Western blot of cold-water washings containing acervular mucilage, concentrated by freeze-drying and probed with UB20. Note that the glycoproteins showed some variation in size and all values quoted in the text are means for a large number of individual gels.

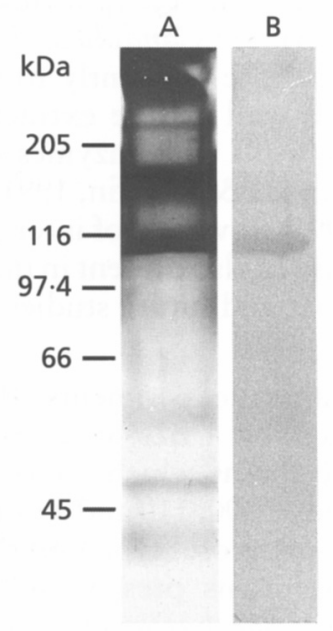

Fig. 4. Binding of hydrophobic polystyrene microspheres (dyed red) to $C$. lindemuthianum spore surface glycoproteins. Glycoproteins were extracted from the spore surface with hot water and Western-blotted. Lanes: $A$, blot probed with mAb UB20; B, blot probed with polystyrene microspheres.

Purified $\operatorname{IgG}$ was used to exclude any possible interference by other serum proteins present in the crude TCS. Adhesion experiments were repeated three times and a representative set of data is shown in Fig. 7. In the absence of $\operatorname{IgG},>90 \%$ of conidia adhered within

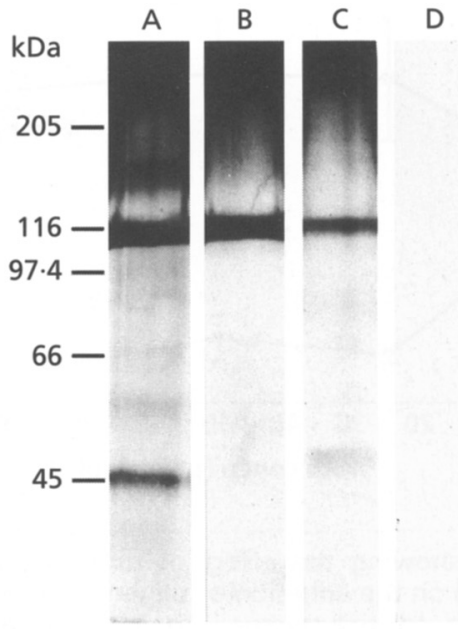

Fig. 5. Western blots of $C$. lindemuthianum spore surface glycoproteins biotinylated using biotin hydrazide via carbohydrate side-chains, followed by extraction with $0.2 \%$ SDS. Lanes: A, blot probed with MAb UB20; B, blot probed with anti-biotin antibodies; $C$, blot of glycoproteins remaining in the spore pellet after extraction, probed with anti-biotin antibodies. Both glycoproteins present in the extract are detected in reduced quantities in the remaining material. Lane $D$, unbiotinylated spore extract probed with anti-biotin antibodies, showing no non-specific labelling.

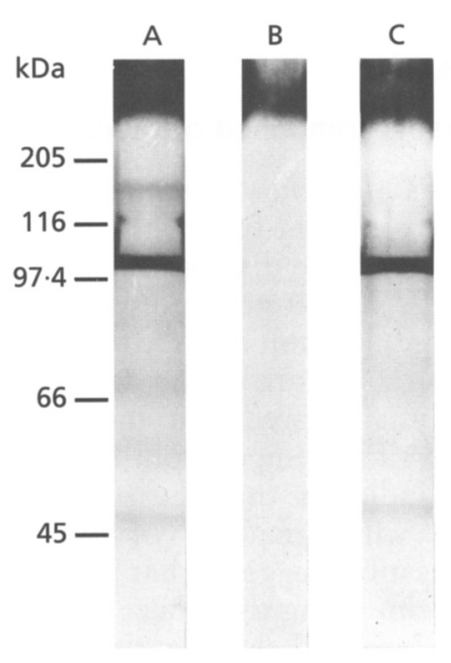

Fig. 6. Western blots of $C$. lindemuthianum glycoproteins extracted from the spore surface with $0.2 \%$ SDS and digested with PNGase and endo- $H$. Lanes: $A$, untreated extract probed with UB20; B, extract digested with PNGase and probed with UB20; $C$, extract digested with endo-H and probed with UB2O.

$30 \mathrm{~min}$ of incubation on polystyrene. Compared to adhesion in the absence of IgG, treatment with UB20 IgG significantly inhibited spore adhesion $(P<0.05)$ at concentrations as low as $6.25 \mu \mathrm{g} \mathrm{ml}^{-1}$ (Fig. 7). In contrast, treatment with UBIM22 IgG had no significant effect on spore adhesion $(P<0.05)$, even at a concentration of $100 \mu \mathrm{g} \mathrm{ml}^{-1}$ (Fig. 7). Young \& Kauss 


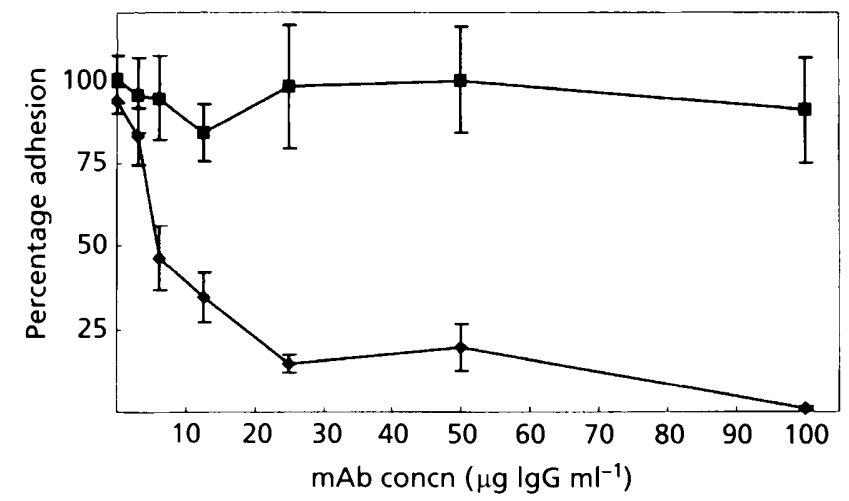

Fig. 7. Graph showing the effect of mAb UB20 IgG ( $)$ or UBIM22 IgG ( $\boldsymbol{\square}$ ) on the adhesion of ungerminated conidia of $C$. lindemuthianum to polystyrene. Conidial suspensions (final concentration $5 \times 10^{5}$ spores $\mathrm{ml}^{-1}$ ) were prepared in water or in solutions of $3 \cdot 125,6 \cdot 25,12 \cdot 5,25,50$ and $100 \mu \mathrm{g} \mathrm{IgG} \mathrm{ml} \mathrm{m}^{-1}$. Percentage adhesion was assessed after $30 \mathrm{~min}$. Bars show the $95 \%$ confidence interval for each data point.

(1984) reported that adhesion of C. lindemuthianum spores was inhibited non-specifically by immunoglobulin and various inert proteins. However, in our experiments inhibition did not result from the nonspecific binding of murine $\operatorname{IgG}$ to the spore surface and/or substratum since UBIM22, which recognizes an antigen not present in spores, did not affect adhesion.

\section{DISCUSSION}

\section{The spore coat is composed of glycoproteins}

The surface of $C$. lindemuthianum spores is made up of two structurally distinct layers, the spore coat and the cell wall, which can be distinguished by TEM of cryofixed and frecze-substituted spores. The spore coat is present on unimbibed conidia, showing that this is a preformed structural feature of the dormant spore. Cytochemical analysis showed that the spore coat differs from the cell wall in composition. Intense staining with $\mathrm{PA} / \mathrm{TCH} / \mathrm{SP}$ indicates that the spore coat is rich in carbohydrate, while removal of the spore coat by Pronase E digestion suggests that this carbohydrate is linked to protein. Using the wheat germ lectin (WGA), we previously localized chitin in the spore cell wall but not in the spore coat (O'Connell et al., 1996). Similarly, in this study, $\beta$-1,3-glucans were detected in the wall but not the spore coat. These results suggest that the spore coat lacks the major structural polysaccharides found in the cell wall and is probably composed largely of glycoproteins. The glycoproteins recognized by $\mathrm{mAb}$ UB20 were shown to be concentrated on the outer surface of the spore coat and, to a lesser extent, at the plasma membrane/cell wall interface. The spore coat of C. lindemuthianum closely resembles the fibrillar coating around cells of Candida albicans, which is composed primarily of mannoproteins (Bobichon et al., 1994; Hazen \& Hazen, 1992). The accumulation of glycoproteins identified by UB20 at the plasma membrane/ wall interface in C. lindemuthianum is also paralleled in
Candida albicans, where labelling with Concanavalin A showed that a thin layer of mannoprotein occurs in a similar location (Bobichon et al., 1994; Tokunaga et al., 1986).

\section{Characterization of glycoproteins extracted from the spore surface}

Western blot analysis showed that treatment of spores with hot water or $0.2 \%$ SDS resulted in the selective extraction of a subset of the glycoproteins recognized by UB20, including two major components at 110 and $>200 \mathrm{kDa}$. Since both these treatments completely removed the spore coat while leaving the cell wall intact, the extracted glycoproteins are probably derived mainly from the spore coat, although some components of the cell wall may also have been extracted. Cell fractionation experiments confirmed that the glycoproteins identified by UB20 are located in the cell wall/spore coat, and biotinylation demonstrated that the 110 and $>200 \mathrm{kDa}$ components are exposed at the spore surface. Taken together with the results of immunogold labelling, the most likely interpretation of these data is that the 110 and $>200 \mathrm{kDa}$ glycoproteins are located in the spore coat.

In contrast to similar studies on Candida albicans and Aspergillus fumigatus, relatively few glycoproteins were extracted from the C. lindemuthianum spore surface (Casanova \& Chaffin, 1991; Casanova et al., 1992; Peñalver et al., 1996). The glycoproteins extracted by the methods used here are unlikely to have been linked covalently to other wall components, such as polysaccharides. However, in Candida albicans, a second set of glycoproteins that are covalently attached to chitin or glucans in the cell wall can be extracted after further treatment of cells/walls with enzymes such as zymolase or chitinase (Casanova \& Chaffin, 1991; Gil et al., 1991; Marcilla et al., 1991). It will be of interest to see whether such glycoproteins are also present in the Colletotrichum cell wall/spore coat and future studies will address this possibility.

Antigen modification experiments showed that the epitope recognized by UB20 is carried on $N$-linked carbohydrate side-chains which are of the complex, or hybrid, type on the $>200,110$ and $45 \mathrm{kDa}$ glycoproteins and of the high-mannose type on the $155 \mathrm{kDa}$ glycoprotein. Glycoproteins present in the cell walls of Candida albicans, Saccharomyces cerevisiae and $A$. fumigatus have been mainly studied using the lectin ConA to identify mannoproteins (Casanova \& Chaffin, 1991; Casanova et al., 1992 ; Peñalver et al., 1996). These glycoproteins generally contain a mixture of $N$ - and $O-$ linked carbohydrate, with the $N$-linked side-chains being of the complex type and containing large amounts of branched mannose chains (Ruiz-Herrera, 1992).

\section{Functional role of spore surface glycoproteins}

Previous studies have shown that C. lindemuthianum spores attach to polystyrene and bean hypocotyls after $1 \mathrm{~h}$ (Young \& Kauss, 1984). However, in this study we 
demonstrate that maximum attachment occurs significantly earlier, after only $30 \mathrm{~min}$. Similarly, Mercure et al. (1994b) found that adhesion of C. graminicola conidia occurred within $30 \mathrm{~min}$, although the level of adhesion $(30-40 \%)$ was much lower than in the present study. Spore attachment in several Colletotrichum species appears to involve hydrophobic interactions, as reported for some other fungal plant pathogens, e.g. Botrytis cinerea and Phyllosticta ampellicida (SelaBuurlage et al., 1991; Young \& Kauss, 1984; Mercure et al., 1994b; Doss et al., 1995; Kuo \& Hoch, 1995). Although such attachment is relatively non-specific (i.e. does not depend on receptor-ligand interactions as in Candida), binding could be mediated by one or more surface glycoproteins. In C. graminicola and Nectria haematococca, mannose-containing glycoproteins were implicated in spore adhesion on the basis that Concanavalin $A$ lectin and polyclonal $\lg G$, respectively, inhibited attachment to polystyrene (Mercure et al., 1994b; Kwon \& Epstein, 1997). Our finding that UB20 IgG blocks adhesion of C. lindemuthianum spores at low concentrations and in an antigen-specific manner suggests that one or more of the glycoproteins recognized by $\mathrm{mAb}$ UB20 are involved in attachment to polystyrene. However, it remains possible that UB20 interferes with this process sterically, by binding to non-adhesive molecules in the spore coat. Being concentrated at the surface of ungerminated conidia, the glycoproteins recognized by UB20 are certainly present at the right time and location to have a role in attachment. The selective binding of polystyrene microspheres to the $110 \mathrm{kDa}$ glycoprotein in blots provides further evidence that this major component of the spore surface could mediate interactions with hydrophobic substrata such as polystyrene. Cloning and disruption of the gene encoding this glycoprotein is required to establish whether it has a role in the attachment of C. lindemuthianum spores to the cuticle of host plants.

\section{ACKNOWLEDGEMENTS}

This work was supported by a BBSRC studentship to Bleddyn Hughes, a BBSRC CASE studentship to Sarah Rawlings and by grants from The Royal Society and Accademia Nazionale dei Lincei to Raffaella Carzaniga. IACR-Long Ashton receives grant-aided support from the Biotechnology and Biological Sciences Research Council of the UK. The work was performed under authority given by MAFF license no PHF870B/ 405/33. The authors thank Dr Peter Holloway (IACR-Long Ashton) for use of the microscope goniometer.

\section{REFERENCES}

Bailey, J. A., O'Connell, R. J., Pring, R. J. \& Nash, C. (1992). Infection strategies of Colletotrichum species. In Colletotrichum - Biology, Pathology and Control, pp. 88-120. Edited by J. A. Bailey \& M. J. Jeger. Wallingford: CAB International.

Bobichon, H., Gache, D. \& Bouchet, P. (1994). Ultrarapid cryofixation of Candida albicans: evidence for a fibrillar reticulated external layer and mannan channels within the cell wall. Cryoletters 15, 161-172.

Casanova, M. \& Chaffin, W. L. (1991). Cell wall glycoproteins of
Candida albicans as released by different methods. I Gen Microbiol 137, 1045-1051.

Casanova, M., Lopez-Ribot, J. L., Martinez, J. P. \& Sentandreu, R. (1992). Characterization of cell wall proteins from yeast and mycelial cells of Candida albicans by labelling with biotin: comparison with other techniques. Infect Immun 60, 4898-4906.

Clement, J. A., Porter, R., Butt, T. M. \& Beckett, A. (1994). The role of hydrophobicity in attachment of urediniospores and sporelings of Uromyces viciae-fabae. Mycol Res 98, 1217-1228.

Doss, R. P., Potter, S. W., Soeldner, A. H., Christian, J. K. \& Fukunaga, L. E. (1995). Adhesion of germlings of Botrytis cinerea. Appl Environ Microbiol 61, 260-265.

Gil, M. L., Casanova, M., Martínez, J. P. \& Sentandreu, R. (1991). Antigenic cell wall mannoproteins in Candida albicans isolates and in other Candida species. J Gen Microbiol 137, 1053-1061.

Goldstein, I. J. \& Poretz, R. D. (1986). Isolation, physicochemical characterization and carbohydrate-binding specificity of lectins. In The Lectins: Properties, Functions and Applications in Biology and Medicine, pp. 33-247. Edited by I. E. Liener, N. Sharon \& I. J. Goldstein. Orlando, FL: Academic Press.

Hazen, K. C. \& Hazen, B. W. (1987). A polystyrene microsphere assay for detecting surface hydrophobicity variations within Candida albicans populations. J Microbiol Methods 6, 289-299.

Hazen, K. C. \& Hazen, B. W. (1992). Hydrophohic surface protein masking by the opportunistic fungal pathogen Candida albicans. Infect Immun 60, 1499-1508.

Howard, R. J. \& O'Donnell, K. L. (1987). Freeze substitution of fungi for cytological analysis. Exp Mycol 11, 250-269.

Johnston, A. \& Thorpe, R. (1987). Immunocytochemistry in Practice. Oxford: Blackwell Scientific Publications.

Jones, G. L., Bailey, J. A. \& O'Connell, R. J. (1995). Sensitive staining of fungal extracellular matrices using colloidal gold. Mycol Res 99, 567-573.

Kăhne, T. \& Ansorge, S. (1994). Non-radioactive labelling and immunoprecipitation analysis of leukocyte surface proteins using different methods of protein biotinylation. I Immunol Methods 168, 209-218.

Kuo, K. \& Hoch, H. C. (1995). Visualization of the extracellular matrix surrounding pycnidiospores, germlings, and appressoria of Phyllosticta ampelicida. Mycologia 87, 759-771.

Kwon, Y. H. \& Epstein, L. (1997). Involvement of the $90 \mathrm{kDa}$ glycoprotein in adhesion of Nectria haematococca macroconidia. Physiol Mol Plant Pathol 51, 287-303.

Lancelle, S. A., Callaham, D. A. \& Hepler, P. K. (1986). A method for rapid freeze fixation of plant cells. Protoplasma 131, 153-165.

Marcilla, A., Elorza, M. V., Mormeneo, S., Rico, H. \& Sentandreu, R. (1991). Candida albicans mycelial wall structure: supramolecular complexes released by Zymolase, chitinase and $\beta$ mercaptoethanol. Arch Microbiol 155, 312-319.

Mercure, E. W., Kunoh, H. \& Nicholson, R. L. (1994a). Adhesion of Colletotrichum graminicola conidia to corn leaves: a requirement for disease development. Physiol Mol Plant Pathol 45, 407-420.

Mercure, E. W., Leite, B. \& Nicholson, R. L. (1994b). Adhesion of ungerminated conidia of Colletotrichum graminicola to artificial hydrophobic surfaces. Physiol Mol Plant Pathol 45, 421-440.

Mercure, E. W., Kunoh, H. \& Nicholson, R. L. (1995). Visualization of materials released from adhered, ungerminated conidia of Colletotrichum graminicola. Physiol Mol Plant Pathol 46, 121-135.

Mims, C. W., Richardson, E. A., Clay, R. P. \& Nicholson, R. L. (1995). Ultrastructure of conidia and the conidium ageing process 
in the plant pathogenic fungus Colletotrichum graminicola. Int $J$ Plant Sci 156, 9-18.

Neumann, A. W. \& Good, R. J. (1979). Techniques of measuring contact angles. In Surface and Colloid Science, vol. 11, pp. 31-91. Edited by R. J. Good \& R. A. Stromberg. New York: Plenum.

Nicholson, R. L. (1992). Colletotrichum graminicola and anthracnose diseases of maize and sorghum. In ColletotrichumBiology, Pathology and Control, pp. 186-202. Edited by J. A. Bailey \& M. J. Jeger. Wallingford: CAB International.

O'Connell, R. J., Pain, N. A., Hutchison, K. A., Jones, G. L. \& Green, J. R. (1996). Ultrastructure and composition of the cell surfaces of infection structures formed by the fungal plant pathogen Colletotrichum lindemuthianum. I Microsc 181, 204-212.

Pain, N. A., O'Connell, R. J., Bailey, J. A. \& Green, J. R. (1992). Monoclonal antibodies which show restricted binding to four Colletotrichum species: C. lindemuthianum, C. malvarum, C. orbiculare, C. trifolii. Physiol Mol Plant Pathol 40, 111-126.

Peñalver, M. C., Casanova, M., Martínez, J. P. \& Gil, M. L. (1996). Cell wall protein and glycoprotein constituents of Aspergillus fumigatus that bind to polystyrene may be responsible for the cell surface hydrophobicity of the mycelium. Microbiology 142, 1597-1604.

Perry, J., Gilligan, M., Green, E., Docherty, H. \& Heath, D. (1990). Monoclonal antibodies to ROS $17 / 2.8$ cells recognise antigens, some of which are restricted to osteoblasts and chondrocytes. J Bone Miner Res 5, 187-200.

Roland, J. C. \& Vian, B. (1991). General preparation and staining of thin sections. In Electron Microscopy of Plant Cells, pp. 1-66. Edited by J. L. Hall \& C. Hawes. London: Academic Press.
Ruiz-Herrera, J. (1992). Fungal Cell Wall: Structure, Synthesis and Assembly. Boca Raton, FL: CRC Press.

Sela-Buurlage, M., Epstein, L. \& Rodriguez, R. J. (1991). Adhesion of ungerminated Colletotrichum musae conidia. Physiol Mol Plant Pathol 39, 345-352.

Tokunaga, M., Kusamichi, M. \& Koike, H. (1986). Ultrastructure of outermost layer of cell wall in Candida albicans observed by rapid-freezing technique. J Electron Microsc 35, 237-246.

Tokuyasu, K. T. (1986). Application of cryoultramicrotomy to immunocytochemistry. J Microsc 143, 139-149.

Van Dyke, C. G. \& Mims, C. W. (1991). Ultrastructure of conidia, conidium germination and appressorium development in the plant pathogenic fungus Colletotrichum truncatum. Can J Bot 69, $2455-2467$.

Viret, O., Toti, L., Chapela, I. H. \& Petrini, O. (1994). The role of the extracellular sheath in recognition and attachment of conidia of Discula umbrinella (Bok \& Br.) Moroleet to the host surface. New Phytol 127, 123-131.

Walther, P., Schweingruber, A.-M., Muller, M. \& Schweingruber, M. E. (1988). Morphological organization of glycoprotein containing cell surface structures in yeast. J Ultrastruct Mol Struct Res 101, 123-136.

Young, D. H. \& Kauss, H. (1984). Adhesion of Colletotrichum lindemuthianum spores to Phaseolus vulgaris hypocotyls and to polystyrene. Appl Environ Microbiol 47, 616-619.

Received 27 November 1998; revised 16 February 1999; accepted 20 May 1999. 